\title{
The anti-oxidant, whitening and anti-wrinkle effects of Castanea crenata inner shell extracts processed by enzyme treatment and pressurized extraction
}

\author{
Yul Ri Gu, Ju Hyeon Kim, Joo-Heon Hong* \\ Department of Food Science and Technology, Daegu Catholic University, Gyeongsan 38430, Korea
}

\section{효소처리 및 가압추출 공정을 이용한 율피 추출물의 항산화, 피부 미백 및 주름개선 효과}

\author{
구율리·김주현 · 홍주헌* \\ 대구가톨릭대학교 식품공학전공
}

\begin{abstract}
In this study, the anti-oxidant, whitening, and anti-wrinkle effects of Castanea crenata inner shell extracts processed by enzyme treatment and pressurized extraction were investigated. The Castanea crenata inner shell was first hydrolyzed using celluclast, viscozyme, or hemicellulase. Then, it was subjected to pressure extraction for different durations $(30,60$, and $120 \mathrm{~min})$. The yields of the Castanea crenata inner shell extracts processed by different enzyme treatments followed by pressurized extraction for different times are in the range of $12.42-29.80 \%$. The total polyphenol, flavonoid, and tannin contents of the C30m (celluclast enzyme and autoclave extracts at $30 \mathrm{~min}$ ) extract were 15.48, 10.82 , and $15.82 \mathrm{~g} / 100 \mathrm{~g}$, respectively. The total sugar content of the $1120 \mathrm{~m}$ (hemicellulase enzyme and autoclave extracts at $120 \mathrm{~min}$ ) extract is $61.07 \mathrm{~g} / 100 \mathrm{~g}$. The 1,1-diphenyl-2-pycrylhydrazyl (DPPH) and 2,2'-azino-bis (3-ethylbenzothiazoline-6-sulfonic acid) (ABTS) radical scavenging activities of the $\mathrm{C30m}$ extract at $1,000 \mu \mathrm{g} / \mathrm{mL}$ are 89.20 , and $81.96 \%$, respectively. The superoxide radical scavenging and feric-reducing antioxidant power of the $\mathrm{C30m}$ extract at $1,000 \mu \mathrm{g} / \mathrm{mL}$ are $67.63 \%$ and $1,324.79 \mu \mathrm{M}$, respectively. Further, the tyrosinase and elastase inhibition activity of the $\mathrm{C30m}$ extract at $1,000 \mu \mathrm{g} / \mathrm{mL}$ are 61.32 , and $61.06 \%$, respectively. Our results indicate that the Castanea crenata inner shell extracts processed by enzyme treatment followed by pressurized extraction could have beneficial effects on facial skin and they should be considered for use in new functional cosmetics.
\end{abstract}

Key words : Castanea crenata, anti-oxidant, whitening, anti-wrinkle, enzyme, pressurize

\section{서 론}

피부 노화현상은 내인성 노화(intrinsic aging)와 광노화 라고도 불리는 외인성 노화(photo aging) 두 가지로 나뉜다. 내인성 노화의 가장 광범위하게 적용되는 원인은 활성산소 종의 축적이며, 이로 인해 나이가 들어감에 따라 피부의

*Corresponding author. E-mail : jhhong@cu.ac.kr Phone : 82-53-850-3218, Fax : 82-53-850-3218

Received 6 December 2017; Revised 18 January 2018; Accepted 26 January 2018.

Copyright (c) The Korean Society of Food Preservation. All rights reserved.
표피와 진피 사이의 결합이 약해지고, 피부각질형성 세포 의 분열 능력 저하로 인해 지질형성 능력이 떨어지게 된다 (1). 이 때, 활성산소종은 슈퍼옥사이드(superoxide, $\mathrm{O}_{2}$ ), 일 중항 산소(singlet oxygen, ${ }^{1} \mathrm{O}_{2}$ ), 과산화수소(hydrogen peroxide, $\mathrm{H}_{2} \mathrm{O}_{2}$ ) 등이 포함되며 이들은 불안정하고 반응성 이 매우 높아서 체내에 과량 존재할 경우 세포의 주요 구성 성분인 지질, 단백질, DNA 등의 손상을 일으켜 산화적 스트 레스를 유발하게 된다 $(2,3)$. 그리고 오랜 시간 자외선 노출 로 인한 외인성 노화는 자외선이 표피를 투과해 진피층까지 깊이 침투함으로써 피부가 얇아지고 주름이 증가되며, 기 미, 주근깨 및 검버섯이 나타난다. 자외선 노출로 색소침착 이 증가하는 이유는 피부 세포가 자외선 흡수에 의한 손상 
을 방어하기 위한 목적으로 멜라닌 색소 생성 유도와 밀접 한 관계가 있으며, 자외선에 의한 피부 노화가 진행되면 멜라닌 증식이 항시적으로 되고 그 결과 기미 및 주근깨 등이 나타난다(4). 이런 노화들이 진행될수록 피부를 구성 하는 물질인 collagen, elastin, hyaluronic acid 등 구조 단백질 을 생성하는 능력이 감소하고 기질 단백질 분해를 유도하여 피부탄력을 떨어뜨리고 피부 주름생성을 야기한다(5). 최 근 연구에 따르면 elastase가 피부 탄력성 섬유의 3차원적 뒤틀림에 중요한 역할을 한다고 보고되었으며(6), 이러한 elastase의 활성 증가는 피부 탄력 섬유를 감소시켜 피부 주름 형성에 기여한다고 알려져 있다(7).

최근에는 과학기술의 발달에 따른 삶의 질 향상으로 사 람들의 관심사는 의식주에서 더 나아가, 개인의 건강과 미 용에 초점이 맞추어지게 되어 남녀노소 할 것 없이 피부미 용에 많은 관심이 집중되고 있으며, 대표적으로 미백과 주 름개선이 주요 관심사에 해당된다(4). 이에 따라 피부 미백 및 주름개선 효과와 관련된 다양한 연구가 진행되고 있는 데, 기존의 미백 및 주름개선 소재인 arbutin, ascorbic acid, kojic acid, hydroquinone, retinol, retinyl palmitate, adenosine 등이 사용되고 있으나 발암성이나 독성과 같은 안정성에 문제점이 있다(8). 이러한 문제점을 해결하기 위해 천연물 소재가 가지고 있는 다양한 생리활성 기능에 많은 관심을 가지면서 기능성 미용소재 개발을 위한 연구가 더욱 활발해 지고 있다(9,10).

율피는 너도 밤나무과(Buna)의 다년생 초목인 밤나무 (Castanea crenata Sieb)의 과실인 밤의 속껍질로 밤의 가공 공정 중에 대량 폐기되고 있지만, 피부를 청결하게 하고 피부에 수분을 공급하거나 피부 수분의 손실을 막아주는 보습작용이 있음이 연구를 통해 밝혀졌다(11). 율피 내에는 tannic acid, gallic acid, catechin 등이 다량 함유되어 있어 유해 환경으로부터 신체 내부에 생성된 반응성이 높은 활성 산소나 자유라디칼 과산화물에 의해 생체성분이 산화되거 나 변성되는 것을 저해하는 천연 항산화제로 사용할 수 있다(12). 특히 율피는 DOPA 자동산화에 대한 저해작용, 피부의 과다한 멜라닌 색소 형성에 의한 피부의 색소 침착 을 억제하며 오래 전부터 피부 미용 재료로 인정받아 왔을 뿐만 아니라 민간에서도 많이 사용되고 있다(13).

따라서 본 연구에서는 밤 가공 부산물인 율피 유래 생리 활성물질을 효율적으로 추출하고자 효소종류별 및 가압추 출 시간에 따라 추출하였으며, 율피 추출물의 기능성 소재 로의 다양한 활용 가능성을 확인하고자 항산화 활성과 피부 미백 및 주름개선 효과에 대해 조사하였다.

\section{재료 및 방법}

\section{실험재료}

본 연구에 사용한 율피는 대명왕밤 품종의 부산물로 경
상남도 합천군 합천밤6차산업화사업단으로부터 제공받았 다. 율피는 동결 건조한 다음 분쇄기(RT-04, Hanli Co., Sejong, Korea)로 분쇄하여 60 mesh 표준망체(Chung Gye Sang Cong Sa, Seoul, Korea)를 통과한 분말을 $-20^{\circ} \mathrm{C}$ 이하에 서 보관하면서 효소분해용 시료로 사용하였다.

\section{율피 추출물 제조}

율피 추출물 제조는 율피 분말 $10 \mathrm{~g}$ 에 20 배의 증류수를 가한 다음 환류냉각추출기로 $100^{\circ} \mathrm{C}, 4$ 시간 열수추출 및 autoclave(HB-506-4, Hanbaek Sci Co., Bucheon, Korea)로 $121^{\circ} \mathrm{C}, 1.2$ 기압, 120 분 가압 추출하였다. 율피 효소 분해물 의 제조에 사용한 3 종의 효소 celluclast(Celluclast $1.5 \mathrm{~L}$ ) 및 viscozyme(Viscozyme L)를 Novozymes Co.(Bagsvaerd, Denmark)에서 구입하였고, hemicellulase(H2125-150KU) 는 Sigma-Ardrich Co.(St. Louis, MO, USA)에서 구입하여 사용하였다. 율피 효소 분해물의 제조는 율피 분말 $10 \mathrm{~g}$ 에 20 배의 증류수를 가한 다음 3 종의 효소를 각각 기질 대비 $2 \%$ 첨가하여 $1 \mathrm{~N} \mathrm{HCl}$ 또는 $1 \mathrm{~N} \mathrm{NaOH}$ 로 최적 $\mathrm{pH}$ 를 조절한 후, shaking incubator(BS-31, Jeio Tech., Daejeon, Korea)에 서 $100 \mathrm{rpm}$ 으로 celluclast 및 viscozyme은 $50^{\circ} \mathrm{C}, 3$ 시간 교반 하고, hemicellulase는 $40^{\circ} \mathrm{C}, 12$ 시간 교반하였다. 효소처리 된 시료는 autoclave(HB-506-4, Hanbaek Sci Co.)로 $121^{\circ} \mathrm{C}$, 1.2 기압에서 예비실험을 통해 선정된 추출시간인 30,60 및 120 분간 가압 추출하고 불순물을 제거하기 위하여 여과 지(Whatman No.2)를 이용하여 여과하였다. 여과된 용액은 감압농축기(Model N-1N, Eyela Co., Tokyo, Japan)로 농축 한 다음, 동결건조기(Free Zone 2.5, Labconco Co., Kansas, $\mathrm{MO}, \mathrm{USA})$ 로 건조하여 $-70^{\circ} \mathrm{C}$ 이하의 암소에 보관하면서 분석용 시료로 사용하였다.

\section{추출수율}

효소처리 및 가압추출에 따른 추출물의 추출수율은 동결 건조(Free Zone 2.5, Labconco Co.)한 다음 건물 중량을 구하 였고 시료 조제에 사용한 원료 건물량에 대한 백분율로 나타내었다.

\section{총 폴리페놀 함량 및 총 플라보노이드 함량}

총 폴리페놀 함량은 Folin-Denis법(14)에 따라 시료 $1 \mathrm{~mL}$ 에 $1 \mathrm{~N}$ Folin Ciocalteu reagent $1 \mathrm{~mL}$ 를 첨가하고 충분히 혼합한 다음 $20 \% \mathrm{Na}_{2} \mathrm{CO}_{3} 1 \mathrm{~mL}$ 를 첨가하여 실온의 암소에 서 30 분간 반응시킨 후 분광광도계(Ultrospec 2100pro, Biochrom Ltd., Cambridge, UK)를 이용하여 $725 \mathrm{~nm}$ 에서 흡광도를 측정하였다. 총 폴리페놀 함량은 gallic acid (Sigma-Aldrich Co.)를 사용하여 작성한 표준곡선으로부터 계산하였다.

총 플라보노이드 함량은 Jia 등(15)의 방법을 응용하여 측정하였다. 시료 $1 \mathrm{~mL}$ 에 $5 \% \mathrm{NaNO}_{2} 150 \mu \mathrm{L}$ 를 혼합하여 
실온에서 6 분간 반응 시킨 후 $10 \% \mathrm{AlCl}_{3} 300 \mu \mathrm{L}$ 와 혼합하여 다시 실온에서 5 분간 반응 시킨 후 $1 \mathrm{~N} \mathrm{NaOH} 1 \mathrm{~mL}$ 와 혼합한 다음 분광광도계(Ultrospec 2100pro, Biochrom Ltd.) 를 이용하여 $510 \mathrm{~nm}$ 에서 흡광도를 측정하였다. 총 플라보 노이드함량은 rutin(Sigma-Aldrich Co.)을 사용하여 작성한 표준곡선으로부터 계산하였다.

\section{총 탄닌 함량 및 총 당 함량}

총 탄닌 함량은 Duval과 Shetty(16)의 방법에 따라 시료 $1 \mathrm{~mL}$ 에 $95 \%$ ethanol $1 \mathrm{~mL}$ 와 증류수 $1 \mathrm{~mL}$ 를 차례로 가하여 충분히 혼합한 다음 $5 \% \mathrm{Na}_{2} \mathrm{CO}_{3}$ 용액 $1 \mathrm{~mL}$ 와 $1 \mathrm{~N}$ Folinciocalteu reagent(Sigma-Aldrich Co.) $0.5 \mathrm{~mL}$ 를 가한 후 실온 에서 60 분간 발색시키고 분광광도계(Ultrospec 2100pro, Biochrom Ltd.)를 이용하여 $725 \mathrm{~nm}$ 에서 흡광도를 측정하였 다. 총 탄닌 함량은 tannic acid(Sigma-Aldrich Co.)를 사용하 여 작성한 표준곡선으로부터 계산하였다.

총 당 함량은 phenol-sulfuric acid 방법(17)을 응용하여 측정하였다. 시료 $1 \mathrm{~mL}$ 와 $5 \%$ phenol $1 \mathrm{~mL}$ 및 진한 $\mathrm{H}_{2} \mathrm{SO}_{4}$ $5 \mathrm{~mL}$ 를 혼합하여 20 분간 반응 시킨 후, 분광광도계 (Ultrospec 2100pro, Biochrom Ltd.)를 이용하여 $470 \mathrm{~nm}$ 에서 흡광도를 측정하였다.

\section{DPPH radical 소거활성 측정}

DPPH radical 소거활성은 1,1-diphenyl-2-pycrylhydrazyl $(\mathrm{DPPH})$ 의 환원력을 이용하여 측정하였다(18). 즉, $\mathrm{DPPH}$ reagent는 DPPH $12 \mathrm{mg}$ 을 absolute ethanol $100 \mathrm{~mL}$ 에 용해한 후 증류수 $100 \mathrm{~mL}$ 첨가하여 흡광도를 $517 \mathrm{~nm}$ 에서 약 1.6 으 로 조정하여 제조하였다. 시료 $0.5 \mathrm{~mL}$ 에 DPPH reagent 5 $\mathrm{mL}$ 를 혼합하여 실온에서 15 분간 반응시킨 후 분광광도계 (Ultrospec 2100pro, Biochrom Ltd.)로 흡광도를 측정하고 아래와 같이 계산하였다.

$$
\text { DPPH radical scavenging activity }(\%)=\left(\frac{\mathrm{S}}{\mathrm{C}}\right) \times 100
$$

S : absorbance of sample at $517 \mathrm{~nm}$

C : absorbance of control at $517 \mathrm{~nm}$

\section{ABTS radical 소거활성 측정}

2,2'-Azino-bis(3-ethylbenzothiazoline-6-sulfonic acid)(ABTS) radical 소거활성(19)은 $7.4 \mathrm{mM} \mathrm{ABTS(Sigma-}$ Aldrich Co.)와 $2.45 \mathrm{mM}$ potassium persulfate를 최종 농도로 혼합하여 실온인 암소에서 24시간 동안 방치하여 $\mathrm{ABTS}^{+}$을 형성시킨 후 $732 \mathrm{~nm}$ 에서 흡광도 값이 $0.70 \pm 0.02$ 가 되게 phosphate buffer saline(PBS, pH 7.4)으로 희석하였다. 희석 된 용액 $180 \mu \mathrm{L}$ 에 시료 $20 \mu \mathrm{L}$ 를 혼합하여 정확히 1 분간 반응시킨 다음 분광광도계(Ultraspec 2100pro, Biochrom Ltd.)를 이용하여 $732 \mathrm{~nm}$ 에서 흡광도를 측정하였다. ABTS radical 소거활성은 추출물의 첨가 전과 후의 차이를 아래와 같이 백분율로 나타내었다.

$$
\text { ABTS radical scavenging activity }(\%)=\left(\frac{S}{C}\right) \times 100
$$

S : absorbance of sample at $732 \mathrm{~nm}$

C : absorbance of control at $732 \mathrm{~nm}$

\section{Superoxide radical 소거활성 측정}

Superoxide radical 소거활성은 Nishikimi 등(20)의 방법에 따라 다음과 같이 측정하였다. 시료 $500 \mu \mathrm{L}$ 에 $0.1 \mathrm{M}$ Tris- $\mathrm{HCl}$ 완충용액( $\mathrm{pH}$ 8.5) $100 \mu \mathrm{L}, 100 \mu \mathrm{M}$ phenazine methosulfate(PMS, Sigma-Aldrich Co.) $200 \mu \mathrm{L}$ 를 혼합하여 반응 시킨 후 $500 \mu \mathrm{L}$ nitro blue tetrazolium(NBT, SigmaAldrich Co.) $200 \mu \mathrm{L}$ 및 $500 \mu \mathrm{M} \beta$-nicotinamide adenine dinucleotide(NADH, Sigma-Aldrich Co.) $400 \mu \mathrm{L}$ 를 첨가하여 실온에서 10 분간 반응시킨 다음 분광광도계(Ultraspec 2100pro, Biochrom Ltd.)를 이용하여 $560 \mathrm{~nm}$ 에서 흡광도를 측정하였다. Superoxide radical 소거활성은 추출물의 첨가 전과 후의 차이를 아래와 같이 백분율로 나타내었다.

Superoxide radical 소거 활성 $(\%)=\left(\frac{\mathrm{S}}{\mathrm{C}}\right) \times 100$

S : absorbance of sample at $560 \mathrm{~nm}$

C : absorbance of control at $560 \mathrm{~nm}$

FRAP (ferric reducing antioxidant power) 측정

FRAP는 Benzie와 Strain의 방법(21)에 따라 다음과 같이 측정하였다. FRAP reagent는 $25 \mathrm{~mL}$ acetate $\operatorname{buffer}(300 \mathrm{mM}$, $\mathrm{pH}$ 3.6)를 $37^{\circ} \mathrm{C}$ 에서 가온한 후, $40 \mathrm{mM} \mathrm{HCl}$ 에 용해한 10 $\mathrm{mM}$ 2,4,6-tris(2-pyridyl)-s-triazine(TPTZ, Sigma-Aldrich Co.) $2.5 \mathrm{~mL}$ 와 $20 \mathrm{mM}$ ferric chloride( $\left.\mathrm{FeCl}_{3}\right) 2.5 \mathrm{~mL}$ 를 첨가하여 제조하였다. 시료 $30 \mu \mathrm{L}$ 에 제조된 FRAP reagent $900 \mu \mathrm{L}$ 와 증류수 $90 \mu \mathrm{L}$ 를 넣고 $37^{\circ} \mathrm{C}$ 에서 10 분간 반응시킨 후 분광광 도계(Ultraspec 2100pro, Biochrom Ltd.)를 이용하여 $510 \mathrm{~nm}$ 에서 흡광도를 측정하였다. FRAP는 $\mathrm{FeSO}_{4} \cdot 7 \mathrm{H}_{2} \mathrm{O}(\mathrm{Sigma}-$ Aldrich Co.)을 정량하여 작성한 표준곡선으로부터 계산하 였다.

\section{Tyrosinase 저해활성 측정}

Tyrosinase 저해활성 측정은 Yagi 등(11)의 방법에 따라 측정하였다. 반응군는 $0.175 \mathrm{M}$ sodium phosphate buffer $(\mathrm{pH}$ 6.8) $0.5 \mathrm{~mL}$ 에 $10 \mathrm{mM} \mathrm{L-DOPA}$ 를 녹인 기질 액 $0.2 \mathrm{~mL}$ 와 시료 $0.1 \mathrm{~mL}$ 의 혼합액에 mushroom tyrosinase $(110 \mathrm{U} / \mathrm{mL})$ $0.2 \mathrm{~mL}$ 를 첨가하여 $25^{\circ} \mathrm{C}$ 에서 2 분간 반응시켜 반응액 중에 생성된 DOPA chrome을 $475 \mathrm{~nm}$ 에서 측정하였다. Tyrosinase 저해활성은 시료용액의 첨가군와 무첨가군의 흡광도 감소율을 나타내었다. 
Tyrosinase inhibition activity $(\%)=\left(\frac{\mathrm{S}}{\mathrm{C}}\right) \times 100$

S : absorbance of sample at $475 \mathrm{~nm}$

C : absorbance of control at $475 \mathrm{~nm}$

\section{Elastase 저해활성 측정}

Elastase 저해활성 측정은 James 등(22)의 방법에 따라 시료를 0.2 M Tris-Cl buffer(pH 8.0)로 희석배수에 따라 희석하고 $(10-1,000 \mu \mathrm{g} / \mathrm{mL})$, 희석된 시료 $20 \mu \mathrm{L}$ 에 buffer 200 $\mu \mathrm{L}$ 를 가한 다음 $0.8 \mathrm{mM} \mathrm{N}$-succinyl-(Ala)3-p-nitroanilide 20 $\mu \mathrm{L}$ 를 가하였다. 이것을 $25^{\circ} \mathrm{C}$ 에서 10 분간 배양한 다음 1.0 $\mu \mathrm{g} / \mathrm{mL}$ 의 porcine pancreatic elastase(PPE)를 $20 \mu \mathrm{L}$ 씩 첨가하 였다. 반응혼합물은 다시 $25^{\circ} \mathrm{C}$ 에서 20 분간 배양한 후 냉침 으로 반응을 정지시키고 $405 \mathrm{~nm}$ 에서 흡광도를 측정하였다. Elastase 저해활성은 시료용액의 첨가군와 무첨가군의 흡광 도 감소율을 나타내었다.

Elastase inhibition activity $(\%)=\left(\frac{S}{C}\right) \times 100$

S : absorbance of sample at $405 \mathrm{~nm}$

C : absorbance of control at $405 \mathrm{~nm}$

\section{통계처리}

모든 실험결과는 IBM SPSS Statistics(19.0, IBM Corp., Armonk, NY, USA)를 이용한 분산분석(ANOVA)을 실시하
였고 각 측정 평균값의 유의성 $(\mathrm{p}<0.05)$ 은 Duncan's multiple range test를 실시하여 검정하였다.

\section{결과 및 고찰}

\section{율피 추출물의 추출수율 및 이화학적 특성}

효소처리 및 가압추출에 따른 율피 추출물의 추출수율, 총 폴리페놀, 총 플라보노이드, 총 탄닌 및 총 당 함량은 Table 1과 같다. 효소종류(celluclast, viscozyme 및 hemicellulase)에 따른 율피 추출물의 추출수율은 12.42$29.80 \%$ 로 나타났으며, celluclast 처리 후 30 분 가압추출 처 리구 $(\mathrm{C} 30 \mathrm{~m})$ 가 $29.80 \%$ 로 가장 높은 추출수율을 나타내 었다.

일반적으로 식물은 폴리페놀 및 플라보노이드 화합물과 같은 2 차 대사산물을 함유하고 있는데, 이들은 방향성 화합 물로 고리구조상 - $\mathrm{OH}$ 기로부터 전자를 공여하여 페놀 고리 구조 공명에 의해 구조적 안정화가 되면서 항산화 활성을 나타낸다(23). 이러한 폴리페놀과 플라보노이드는 항산화, 항염증 및 항암 등 생리활성에 관여하는 것으로 최근 많은 연구에서 보고되고 있다. 총 폴리페놀, 총 플라보노이드 및 총 탄닌 함량은 $\mathrm{C} 30 \mathrm{~m}$ 추출물에서 각각 $22.69 \mathrm{~g} / 100 \mathrm{~g}$, $12.13 \mathrm{~g} / 100 \mathrm{~g}$ 및 $21.66 \mathrm{~g} / 100 \mathrm{~g}$ 으로 가장 높은 함량을 나타내 었고 모든 효소 처리구간에서 가압추출 시간이 증가함에 따라 함량은 감소하였으며, 열수추출물 $(\mathrm{HE})$ 에서 각각 $15.48 \mathrm{~g} / 100 \mathrm{~g}, 10.82 \mathrm{~g} / 100 \mathrm{~g}$ 및 $14.90 \mathrm{~g} / 100 \mathrm{~g}$ 으로 가장

Table 1. The yield, total polyphenol, total flavonoid, total tannin, and total sugar contents of Castanea crenata inner shell extracts by enzyme treatment and pressurized extraction

\begin{tabular}{cccccc}
\hline Sample $^{1)}$ & $\begin{array}{c}\text { Yield } \\
\left(\mathrm{DB}^{2)}, \%\right)\end{array}$ & $\begin{array}{c}\text { Total polyphenol } \\
\left(\mathrm{GA}^{3)}, \mathrm{g} / 100 \mathrm{~g}\right)\end{array}$ & $\begin{array}{c}\text { Total flavonoid } \\
(\text { Rutin, g/100) }\end{array}$ & $\begin{array}{c}\text { Total tannin } \\
\left(\mathrm{TA} \mathrm{A}^{4)}, \mathrm{g} / 100\right)\end{array}$ & $\begin{array}{c}\text { Total sugar } \\
(\mathrm{Glucose}, \mathrm{g} / 100)\end{array}$ \\
\hline $\mathrm{HE}$ & $14.30 \pm 0.09^{\mathrm{es})}$ & $15.48 \pm 0.08^{\mathrm{e}}$ & $10.82 \pm 0.43^{\mathrm{a}}$ & $14.90 \pm 0.23^{\mathrm{g}}$ & $38.53 \pm 0.19^{\mathrm{g}}$ \\
$\mathrm{AE}$ & $19.50 \pm 0.11^{\mathrm{d}}$ & $18.52 \pm 0.31^{\mathrm{c}}$ & $11.94 \pm 0.19^{\mathrm{b}}$ & $17.03 \pm 0.38^{\mathrm{f}}$ & $40.42 \pm 1.37^{\mathrm{h}}$ \\
$\mathrm{C} 30 \mathrm{~m}$ & $29.80 \pm 0.14^{\mathrm{a}}$ & $22.69 \pm 0.26^{\mathrm{a}}$ & $12.13 \pm 0.31^{\mathrm{a}}$ & $21.66 \pm 0.45^{\mathrm{a}}$ & $37.60 \pm 0.16^{\mathrm{h}}$ \\
$\mathrm{C} 6 \mathrm{~m}$ & $19.90 \pm 0.11^{\mathrm{d}}$ & $18.54 \pm 0.34^{\mathrm{c}}$ & $11.62 \pm 0.20^{\mathrm{a}}$ & $17.66 \pm 0.17^{\mathrm{d}}$ & $47.31 \pm 0.49^{\mathrm{e}}$ \\
$\mathrm{C} 120 \mathrm{~m}$ & $12.42 \pm 0.03^{\mathrm{f}}$ & $17.54 \pm 0.11^{\mathrm{d}}$ & $10.49 \pm 0.32^{\mathrm{b}}$ & $17.05 \pm 0.24^{\mathrm{e}}$ & $54.89 \pm 1.99^{\mathrm{c}}$ \\
V30m & $27.08 \pm 0.29^{\mathrm{b}}$ & $21.64 \pm 0.33^{\mathrm{b}}$ & $12.01 \pm 0.33^{\mathrm{a}}$ & $20.82 \pm 054^{\mathrm{b}}$ & $43.07 \pm 0.32^{\mathrm{f}}$ \\
V60m & $19.60 \pm 0.34^{\mathrm{d}}$ & $21.20 \pm 0.29^{\mathrm{b}}$ & $11.70 \pm 0.29^{\mathrm{a}}$ & $20.08 \pm 0.21^{\mathrm{c}}$ & $51.76 \pm 0.73^{\mathrm{d}}$ \\
V120m & $14.30 \pm 0.27^{\mathrm{e}}$ & $16.64 \pm 0.16^{\mathrm{d}}$ & $11.00 \pm 0.37^{\mathrm{b}}$ & $15.79 \pm 0.33^{\mathrm{f}}$ & $56.22 \pm 0.79^{\mathrm{c}}$ \\
$\mathrm{H} 30 \mathrm{~m}$ & $28.92 \pm 0.31^{\mathrm{ab}}$ & $21.32 \pm 0.41^{\mathrm{b}}$ & $11.82 \pm 0.18^{\mathrm{a}}$ & $20.16 \pm 0.38^{\mathrm{c}}$ & $50.97 \pm 0.75^{\mathrm{d}}$ \\
$\mathrm{H} 60 \mathrm{~m}$ & $25.41 \pm 0.33^{\mathrm{c}}$ & $15.83 \pm 0.18^{\mathrm{e}}$ & $9.82 \pm 0.17^{\mathrm{c}}$ & $15.16 \pm 0.14^{\mathrm{g}}$ & $58.96 \pm 0.68^{\mathrm{b}}$ \\
$\mathrm{H} 120 \mathrm{~m}$ & $15.44 \pm 0.46^{\mathrm{e}}$ & $15.53 \pm 0.27^{\mathrm{e}}$ & $9.63 \pm 0.16^{\mathrm{c}}$ & $14.54 \pm 029^{\mathrm{h}}$ & $61.07 \pm 1.08^{\mathrm{a}}$ \\
\hline
\end{tabular}

${ }^{1)} \mathrm{HE}$, hot-water extracts from Castanea crenata inner shell; AE, autoclave extracts from Castanea crenata inner shell; C30m, C60m, and C120m, autoclave extracts 30 , 60, and $120 \mathrm{~min}$ ) of celluclast enzyme treatment from Castanea crenata inner shell; V $30 \mathrm{~m}, \mathrm{~V} 60 \mathrm{~m}$, and V120 , autoclave extracts $(30,60$, and $120 \mathrm{~min})$ of viscozyme enzyme treatment from Castanea crenata inner shell; $\mathrm{H} 30 \mathrm{~m}, \mathrm{H} 60 \mathrm{~m}$, and $\mathrm{H} 120 \mathrm{~m}$, autoclave extracts $(30,60$, and $120 \mathrm{~min})$ of hemicellulase enzyme treatment from Castanea crenata inner shell. ${ }^{2)} \mathrm{DB}$, dry basis.

${ }^{3)} \mathrm{GA}$, gallic acid.

${ }^{4)} \mathrm{TA}$, tannic acid

${ }^{5)}$ Means \pm SD ( $\left.n=3\right)$ with different letters $(a-h)$ within column are significantly different by Duncan's multiple range test $(p<0.05)$. 
낮은 함량을 나타내었다. Choi 등(24)의 연구에서 총 폴리 페놀 함량은 율피 발효추출물과 율피 열수추출물이 유사하 게 나타났으며, 총 플라보노이드 함량은 율피 발효추출물 이 율피 열수추출물에 비해 약간 감소하는 경향을 나타내었 다. 또한 Jo 등(25)은 대추혼합물의 발효에 따른 폴리페놀 함량의 변화는 크지 않았다고 보고하여 발효보다 효소처리 및 가압 추출 공정이 율피유래 생리활성물질 추출에 보다 효과적인 것으로 판단된다. 또한 효소분해에 의한 생리활 성물질 함량의 증가는 고분자 물질(다당류 및 단백질 등)과 결합한 페놀성 화합물이 효소처리 과정에서 분해되어 저분 자 페놀성 화합물로 전환된 것으로 사료된다(26).

총 당 함량은 hemicellulase 처리 후 120 분 가압추출 처리 구(H120m)가 $61.07 \mathrm{~g} / 100 \mathrm{~g}$ 으로 가장 높은 함량을 나타내었 으며, 총 폴리페놀, 총 플라보노이드 및 총 탄닌 함량과 달리 모든 효소 처리구간에서 가압추출 시간이 증가함에 따라 함량이 증가하였다. 율피에는 hemicellulose와 상호 연결된 다당류가 많아 hemicellulase 효소분해를 통해 총 당 함량이 증가하고, autoclave를 이용한 가압추출은 세포 벽 또는 단백질의 변성 및 파괴에 영향을 주어 세포 내의 용매 출입이 용이해져 생리활성물질의 추출효율이 증진된 것으로 사료된다(27,28).

\section{율피 추출물의 항산화 활성}

유해 산소와 같은 자유전자기는 강력한 산화제로 화학적 안정을 위해 다른 물질과 결합하는 특징이 있다. 이러한 자유전자기는 피부 내 세포조직과 무분별한 결합으로 피부 의 노화를 촉진하는데 이러한 피부 노화의 원인인 자유전자 기의 활동을 방해하는 것이 항산화제의 역할이다. 또한, 피부색소형성의 주요 원인인 자외선에 의해 발생한 활성산 소가 피부색소 형성을 촉진한다는 매커니즘이 밝혀지면서 활성산소를 소거하는 것이 melanin 색소 형성억제에 효과 적이라는 연구보고가 있다(29,30).

효소처리 및 가압추출에 따른 율피 추출물의 DPPH 및 ABTS radical 소거활성은 Fig. 1, 2와 같다. DPPH 및 ABTS radical 소거활성은 모든 시료에서 농도 의존적으로 증가하 였으며, 다른 추출물보다 효소처리 및 가압추출물에서 높 은 소거활성이 나타났다. DPPH radical 소거활성은 $\mathrm{C} 30 \mathrm{~m}$ 추출물에서 $89.20 \%(1,000 \mu \mathrm{gg} / \mathrm{mL})$ 으로 가장 높은 소거활성 을 나타내었으며, viscozyme 및 hemicellulase 처리구간은 가압추출 시간에 따라 유사한 소거활성을 나타내었다. ABTS radical 소거활성 또한 $\mathrm{C} 30 \mathrm{~m}$ 추출물에서 $81.96 \%$ $(1,000 \mathrm{\mu g} / \mathrm{mL})$ 로 가장 높은 함량을 나타내었으며, 모든 효소 처리구간에서 대체로 가압추출 시간이 증가함에 따라 소거 활성이 감소하는 경향을 나타내어 DPPH radical 소거활성 과 유사하게 나타났다. $\operatorname{Kim}$ 등(31)은 다양한 약용식물의 폴리페놀 함량 및 항산화 활성 간에 밀접한 양의 상관관계 가 있다고 보고하였으며, Yoo 등(32) 역시 감잎 추출물에서
폴리페놀 화합물이 증가할수록 DPPH radical 소거활성이 비 례적으로 증가한다고 나타내어 본 연구와 유사하게 나타났다.

(A)



(B)



(C)

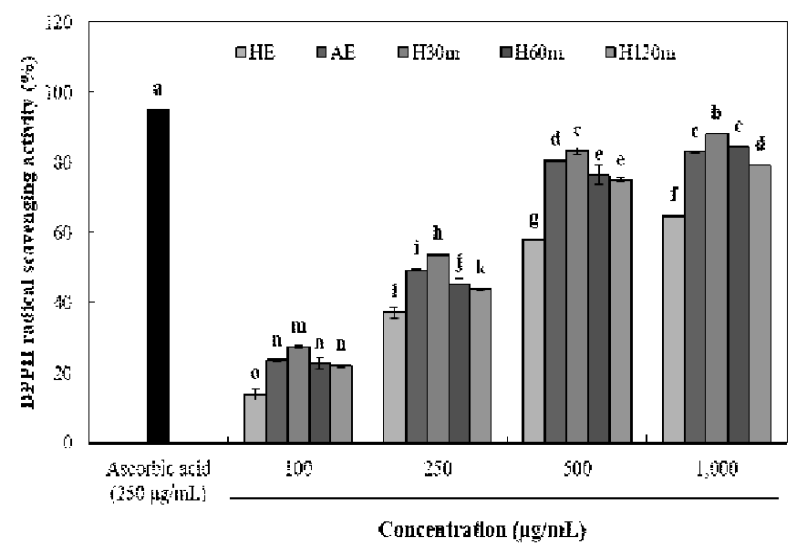

Fig. 1. DPPH radical scavenging activity of Castanea crenata inner shell extracts by enzyme treatment and pressurized extraction.

(A), celluclast enzyme and autoclave extracts (30,60, and $120 \mathrm{~min}$ ) from Castanea crenata inner shell; (B), viscozyme enzyme and autoclave extracts (30, 60, and 120 min) from Castanea crenata inner shell; (C), hemicellulase enzyme and autoclave extracts (30, 60, and $120 \mathrm{~min})$ from Castanea crenata inner shell.

Means \pm SD $(n=3)$ with different letters $(a-q)$ above bars are significantly different by Duncan's multiple range test $(\mathrm{p}<0.05)$. 
(A)

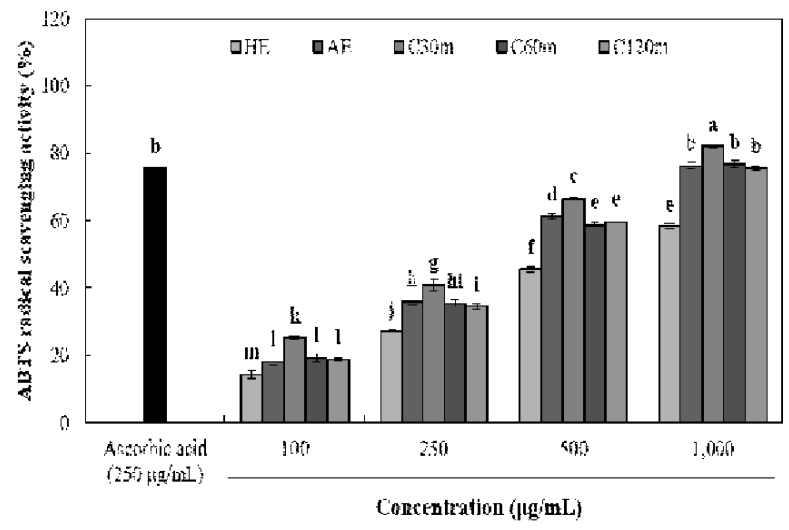

(B)

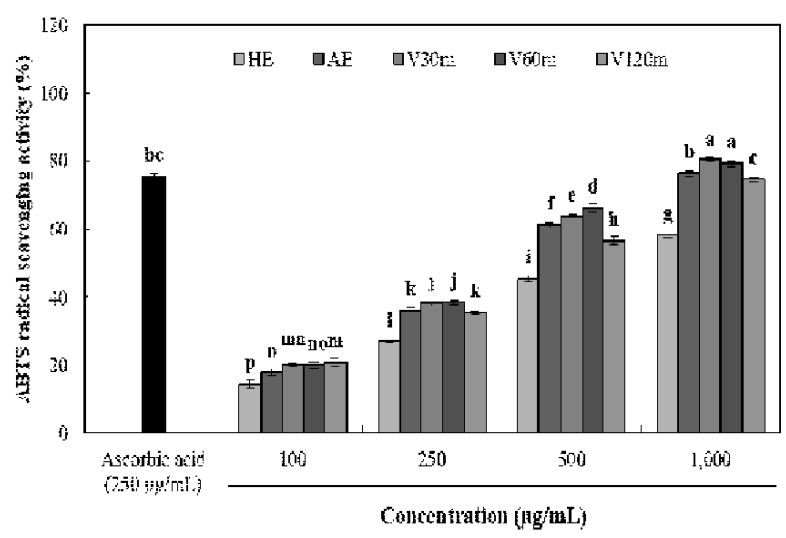

(C)

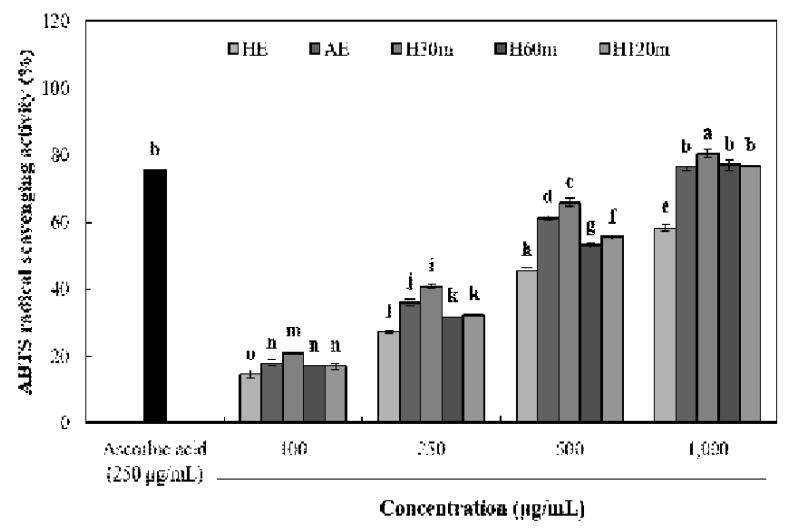

Fig. 2. ABTS radical scavenging activity of Castanea crenata inner shell extracts by enzyme treatment and pressurized extraction.

(A), celluclast enzyme and autoclave extracts $(30,60$, and $120 \mathrm{~min}$ ) from Castanea crenata inner shell; (B), viscozyme enzyme and autoclave extracts (30,60, and 120 min) from Castanea crenata inner shell; (C), hemicellulase enzyme and autoclave extracts (30, 60, and $120 \mathrm{~min})$ from Castanea crenata inner shell.

Means \pm SD $(n=3)$ with different letters $(a-p)$ above bars are significantly different by Duncan's multiple range test $(\mathrm{p}<0.05)$.

효소처리 및 가압추출에 따른 율피 추출물의 superoxide radical 소거활성 및 FRAP 활성은 Fig. 3, 4와 같다. Superoxide radical 소거활성 및 FRAP 활성은 $\mathrm{C} 30 \mathrm{~m}$ 추출물 에서 각각 $67.63 \%(1,000 \mu \mathrm{g} / \mathrm{mL})$ 및 $1,324.79 \mu \mathrm{M}(1,000 \mu$
(A)



(B)



(C)

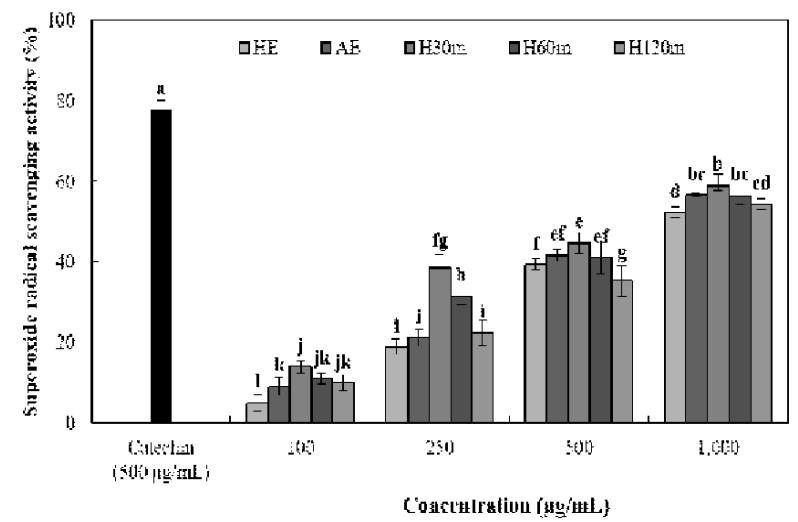

Fig. 3. Superoxide radical scavenging activity of Castanea crenata inner shell extracts by enzyme treatment and pressurized extraction.

(A), celluclast enzyme and autoclave extracts (30, 60, and $120 \mathrm{~min}$ ) from Castanea crenata inner shell; (B), viscozyme enzyme and autoclave extracts $(30,60$, and 120 min) from Castanea crenata inner shell; (C), hemicellulase enzyme and autoclave extracts (30, 60, and $120 \mathrm{~min})$ from Castanea crenata inner shell.

Means $\pm S D(n=3)$ with different letters $(a-m)$ above bars are significantly different by Duncan's multiple range test $(\mathrm{p}<0.05)$.

$\mathrm{g} / \mathrm{mL}$ )로 가장 높은 소거활성 및 활성을 나타내었으며, 모든 효소 처리구간에서 가압추출 시간이 증가함에 따라 감소하 는 유사한 경향을 나타내었다. 또한 $\mathrm{HE}$ 추출물은 각각 $52.34 \%(1,000 \mu \mathrm{g} / \mathrm{mL})$ 및 $1,061.43 \mu \mathrm{M}(1,000 \mu \mathrm{g} / \mathrm{mL})$ 으로 가 
(A)



(B)

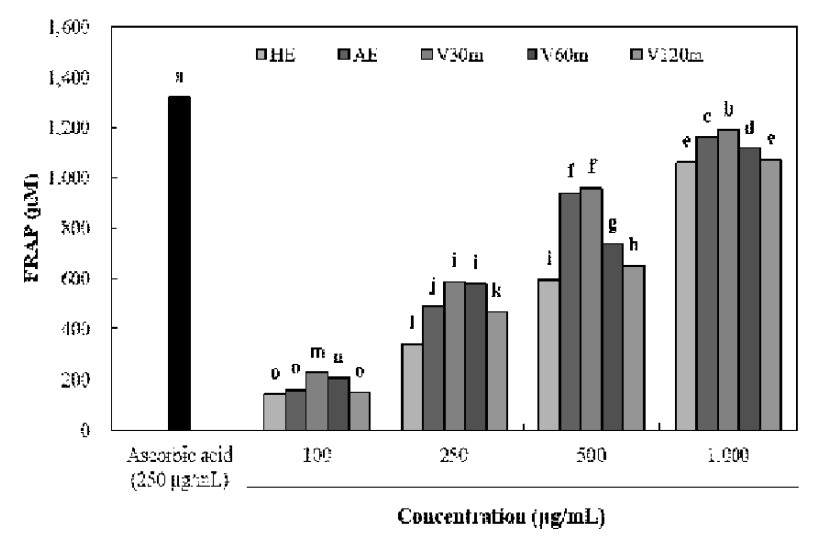

(C)



Fig. 4. FRAP (ferric reducing antioxidant power) activity of Castanea crenata inner shell extracts by enzyme treatment and pressurized extraction.

(A), celluclast enzyme and autoclave extracts $(30,60$, and $120 \mathrm{~min})$ from Castanea crenata inner shell; (B), viscozyme enzyme and autoclave extracts (30,60, and 120 min) from Castanea crenata inner shell; (C), hemicellulase enzyme and autoclave extracts (30, 60, and $120 \mathrm{~min})$ from Castanea crenata inner shell.

Means $\pm S D(n=3)$ with different letters (a-r) above bars are significantly different by Duncan's multiple range test $(\mathrm{p}<0.05)$.

장 낮은 소거활성 및 활성을 나타내었다. Lee 등(12)은 국내 산 밤에 존재하고 있는 gallic acid 및 catechin은 밤의 외피에 비해 내피에 더 많이 존재하므로 율피는 높은 항산화 활성
을 나타낸다고 보고하여, 이를 근거로 본 연구의 효소처리 및 가압추출 공정을 통해 율피에 함유되어 있는 gallic acid 및 catechin 등의 페놀성 화합물들의 추출이 향상되어 우수 한 항산화 활성을 나타낸 것으로 사료된다. 하지만 가압추 출 시간이 증가함에 따라 항산화 활성이 감소하는 것은 Kwon 등(33)의 연구와 같이 높은 온도에서 오랜 처리시간 에 의해 탄화가 많이 진행되어 생리활성물질이 많이 파괴되 어 활성이 떨어진 것으로 사료된다.

\section{Tyrosinase 저해활성}

멜라닌은 피부, 머리카락, 눈동자 등 생물체에 널리 분포 되어 있는 색소 성분으로 인체 표피층의 melanocyte 색소 세포 내의 melanosome에서 합성되는데, tyrosinase 효소에 의해 tyrosine을 시발 물질로 하여 3,4-dihydroxy-phenylalanine(DOPA) 또는 DOPA quinene으로 산화 및 중합 반응 으로 멜라닌이 생합성 된다 $(10,34)$. 생합성된 멜라닌은 자 외선과 같은 피부자극에 대해 저항력을 높여주지만, 과도 한 멜라닌 합성은 색소 침착을 유도하기 때문에 tyrosinase 저해활성 측정은 피부 미백효과를 나타내는 하나의 중요한 지표로 보고 있다(35). 효소처리 및 가압추출에 따른 율피 추출물의 tyrosinase 저해활성은 Fig. 5 와 같다. $\mathrm{C} 30 \mathrm{~m}$ 추출 물에서 $61.32 \%(1,000 \mu \mathrm{g} / \mathrm{mL})$ 로 가장 높은 저해활성을 나타 내었으며, $\mathrm{HE}$ 추출물에서는 $33.97 \%(1,000 \mu \mathrm{g} / \mathrm{mL})$ 로 가장 낮은 저해활성을 나타내었다. 효소 종류에 따른 tyrosinase 저해활성은 celluclast, viscozyme 및 hemicellulase 순으로 높은 저해활성을 나타내었으며, 가압추출 시간에 따른 tyrosinase 저해활성은 모든 효소 처리구간에서 가압추출 시간이 증가함에 따라 감소하는 경향을 나타내었다. 일반 적으로, 페놀성 화합물을 다량 함유하는 약재와 그 추출물 은 높은 항산화 활성을 갖기 때문에, tyrosinase에 의한 가역 적 산화반응을 통해 발생하는 물질들은 환원시켜 멜라닌 생합성 반응을 억제시키는 특성을 나타낸다(36). 또한 페놀 성 화합물은 tyrosinase의 기질인 tyrosine과 구조적으로 유 사하여 기질 유사체의 역할을 함으로써, tyrosinase의 활성 을 저해하고 미백효과를 가진다(37). 이에 Yang 등(38)은 율피가 tyrosinase 저해활성 뿐만 아니라 tyrosinase 유전자 의 발현을 억제하는 효과가 있다고 보고하였고, Yang 등 (39)의 연구에 따라 율피가 멜라닌 색소의 생합성을 효과적 으로 제어할 수 있는 천연물질이라 판단된다.

\section{Elastase 저해활성}

Elastin은 진피 내 전체 단백질의 $2 \%$ 뿐이지만 사람의 피부가 탄력을 갖고 생리적인 기능을 하는 데에 중요한 역할을 한다. Elastin과 collagen 단백질을 만드는 효소와 이들을 분해하는 효소가 균형을 유지해야 정상의 피부로 탄력과 구조를 갖출 수 있다. Elastase의 활성이 높아지게 되면 collagen을 비특이적으로 분해하여 피부의 주름 및 
(A)



(B)

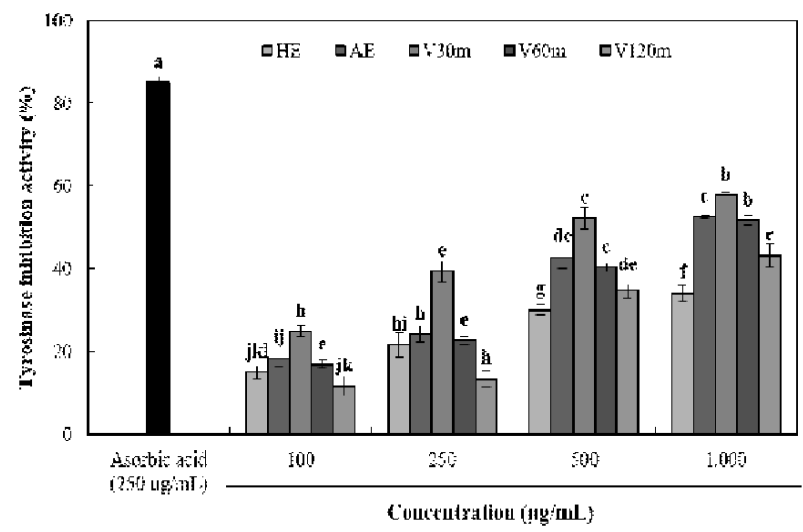

(C)

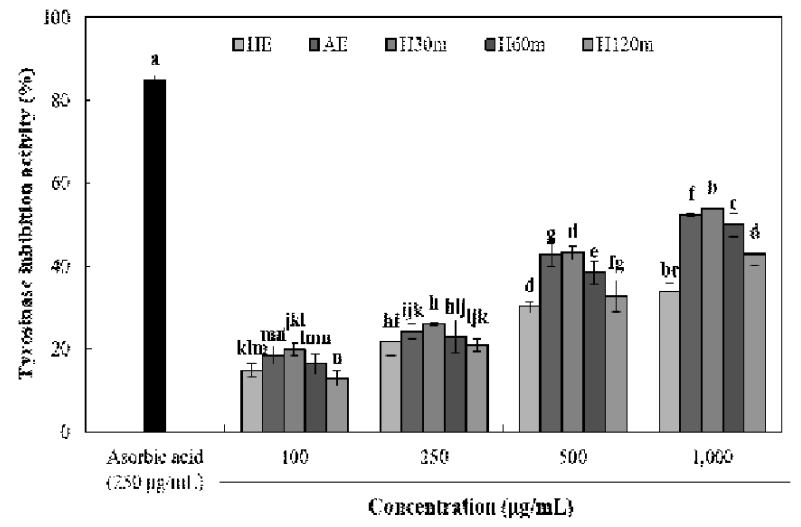

Fig. 5. Tyrosinase inhibition activity of Castanea crenata inner shell extracts by enzyme treatment and pressurized extraction.

(A), celluclast enzyme and autoclave extracts $(30,60$, and $120 \mathrm{~min})$ from Castanea crenata inner shell; (B), viscozyme enzyme and autoclave extracts $(30,60$, and 120 min) from Castanea crenata inner shell; (C), hemicellulase enzyme and autoclave extracts (30, 60, and $120 \mathrm{~min})$ from Castanea crenata inner shell.

Means \pm SD $(n=3)$ with different letters $(a-n)$ above bars are significantly different by Duncan's multiple range test $(\mathrm{p}<0.05)$.

탄력성 소실 등을 유발하게 되므로 elastase 저해제는 피부 에 탄력을 주고 주름을 개선하는 효과가 있다 $(40,41)$. 효소 처리 및 가압추출에 따른 율피 추출물의 elastase 저해활성 은 Fig. 6과 같다. $\mathrm{C} 30 \mathrm{~m}$ 추출물에서 $61.06 \%(1,000 \mu \mathrm{g} / \mathrm{mL})$ 로
(A)

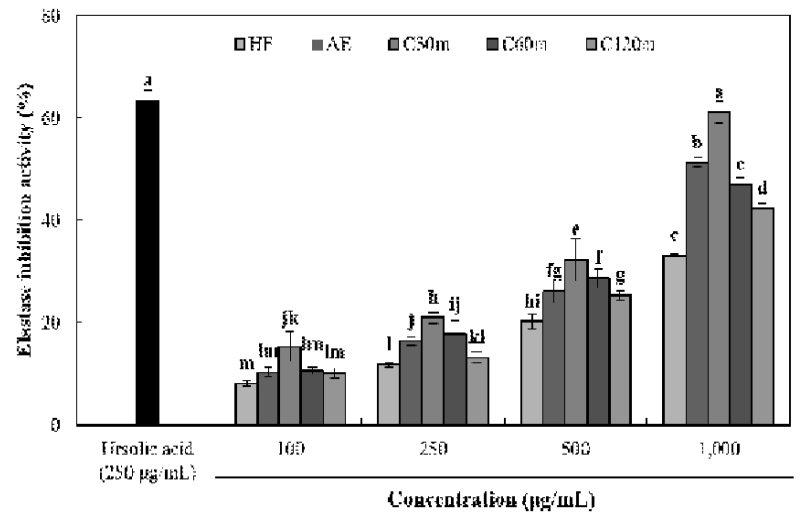

(B)



(C)



Fig. 6. Elastase inhibition activity of Castanea crenata inner shell extracts by enzyme treatment and pressurized extraction.

(A), celluclast enzyme and autoclave extracts (30, 60, and $120 \mathrm{~min}$ ) from Castanea crenata inner shell; (B), viscozyme enzyme and autoclave extracts (30, 60, and 120 min) from Castanea crenata inner shell; (C), hemicellulase enzyme and autoclave extracts (30, 60, and $120 \mathrm{~min}$ ) from Castanea crenata inner shell.

Means \pm SD $(n=3)$ with different letters $(a-m)$ above bars are significantly different by Duncan's multiple range test $(\mathrm{p}<0.05)$.

가장 높은 저해활성을 나타내었고 모든 효소 처리구간에서 가압추출 시간이 증가함에 따라 감소하는 경향을 나타내었 다. 또한 $\mathrm{HE}$ 추출물에서는 $33.03 \%(1,000 \mu \mathrm{g} / \mathrm{mL})$ 로 가장 낮은 저해활성을 나타내어 tyrosinase 저해활성과 유사한 
경향을 나타내었다. Jeong 등(42)의 연구에서 율피 $60 \%$ 메 탄올 추출물은 $1,000 \mu \mathrm{g} / \mathrm{mL}$ 농도에서 $42.88 \%$ 로 나타났으 며, Jang 등(13)의 연구에서는 율피 아세톤 추출물이 1,000 $\mu \mathrm{g} / \mathrm{mL}$ 농도에서 $51.00 \%$ 로 나타났다. 또한 Kwak 등(43)이 보고한 노화억제와 관련된 각종 약용식물인 모과나무, 계 피차, 마, 조각자, 저령의 열수 추출물의 elastase 저해활성이 $1,000 \mathrm{\mu g} / \mathrm{mL}$ 농도에서 각각 $54 \%, 52 \%, 51 \%, 45 \%$, 및 $57 \%$ 의 저해활성을 나타내었다. 이는 본 연구의 $\mathrm{C} 30 \mathrm{~m}$ 추출물보다 낮은 저해활성을 나타내어 효소처리 및 가압추출 공정을 이 용한 추출물의 elastase 저해활성이 더 높은 것을 확인하였다.

\section{요 약}

본 연구에서는 율피 추출물을 이용하여 화장품 소재로서 의 기능성을 조사하고자 효소종류별 및 가압추출 시간별에 따른 항산화 활성과 피부 미백 및 주름개선 효과를 실시하 였다. 효소 종류별 및 가압추출 시간에 따른 율피 추출물의 추출수율은 $12.42-29.80 \%$ 로, $\mathrm{C} 30 \mathrm{~m}$ 추출물이 $29.80 \%$ 로 가 장 높게 나타났다. 이화학적 특성으로 총 폴리페놀, 총 플라 보노이드 및 총 탄닌 함량은 모두 $\mathrm{C} 30 \mathrm{~m}$ 추출물 $(1,000 \mu$ $\mathrm{g} / \mathrm{mL}$ )에서 각각 $22.69 \mathrm{~g} / 100 \mathrm{~g}, 12.13 \mathrm{~g} / 100 \mathrm{~g}$ 및 $21.66 \mathrm{~g} / 100$ $\mathrm{g}$ 으로 높은 함량을 나타내었으며, 총 당 함량은 $\mathrm{H} 120 \mathrm{~m}$ 추출물 $(1,000 \mathrm{\mu g} / \mathrm{mL})$ 에서 $61.07 \mathrm{~g} / 100 \mathrm{~g}$ 으로 높은 함량을 나타내었다. 항산화 활성으로 DPPH radical 소거활성, ABTS radical 소거활성, superoxide radical 소거활성 및 FRAP 활성 모두 $\mathrm{C} 30 \mathrm{~m}$ 추출물 $(1,000 \mu \mathrm{g} / \mathrm{mL})$ 에서 각각 $89.20 \%, 81.96 \%, 67.63 \%$ 및 $1,324.79 \mu \mathrm{M}$ 로 높은 항산화 활성을 나타내었으며, 모든 효소 처리구간에서 가압추출 시간이 증가함에 따라 항산화 활성이 감소하였다. 피부 미 백 및 주름개선 효과를 확인하기 위해 tyrosinase 및 elastase 저해활성을 측정한 결과 $\mathrm{C} 30 \mathrm{~m}$ 추출물 $(1,000 \mu \mathrm{g} / \mathrm{mL})$ 에서 각각 $61.32 \%$ 및 $61.06 \%$ 로 높은 저해활성을 나타내었으며, $\mathrm{HE}$ 추출물에서 가장 낮은 저해활성을 나타내었다. 이는 효소처리 및 가압추출에 의해 율피의 생리활성물질이 많이 용출된 것으로 판단되며, 율피의 새로운 추출공정 확립을 통해 항산화, 피부 미백 및 주름개선에 효과가 있는 항노화 기능성 소재로 화장품 제조용 원료 로 적합함을 확인하였 다.

\section{감사의 글}

본 연구는 합천밤6차산업화사업단에서 지원하는 연구 용역사업의 연구수행으로 인한 결과물임을 밝힙니다.

\section{References}

1. Fisher GJ, Talwar HS, Lin J, Voorhees JJ (1999) Molecular mechanisms of photoaging in human skin in vivo and their prevention by all-trans retinoic acid. Photochem Photobiol, 69, 154-157

2. Halliwell B, Aeschbach R, Lliger J, Aruoma OI (1995) The characterization of antioxidants. Food Chem Toxicol, 33, 601-617

3. Valko M, Leibfritz D, Moncol J, Cronin MT, Mazur M, Telser J (2007) Free radicals and antioxidants in normal physiological functions and human disease. Int $\mathrm{J}$ Biochem Cell Biol, 39, 44-84

4. Wang KH, Lin RD, Hsu FL, Huang YH, Chang HC, Huang CY, Lee MH (2006) Cosmetic applications of selected traditional chinese herbal medicines. J Ethnopharmacol, 106, 353-359

5. Brenneisen P, Sies H, Scharffetter-Lochanek K (2002) Ultraviolet-B irradiation and matrix metalloproteinase: from induction via signaling to initial events. Ann N Y Acad Sci, 973, 31-43

6. Philips N, Keller T, Hendrix C, Hamilton S, Arena R, Tuason M, Gonzalez S (2007) Regulation of the extracellular matrix remodeling by lutein in dermal fibroblasts, melanoma cells, and ultraviolet radiation exposed fibroblasts. Arch Dermatol Res, 299, 373-379

7. Tsukahara K, Nakagawa H, Moriwaki S, Takema Y, Fujimura T, Imokawa G (2006) Inhibition of ultravioletB-induced wrinkle formation by an elastase-inhibiting herbal extract: implication for the mechanism underlying elastase-associated wrinkles. Int J Dermatol, 45, 460-468

8. Joo SY (2013) Antioxidant activities of medicinal plant extracts. J Korean Soc Food Sci Nutr, 42, 512-519

9. Kang MC, Lee JY, Ko RK, Kim HB, Hong SH, Kim GO (2008) Melanin inhibitory effect and anti-inflammatory effects of Dictyota corlacca extracts derived from adjacent sea of the Jeju island. Korean J biotechnol Bioeng, 23, 311-316

10. Jung SW, Lee NK, Kim SJ, Han D (1995) Screening of tyrosinase inhibitor from plants. Korean J Food Sci Technol, 27, 891-896

11. Yagi A, Kanbara T, Morinobu N (1986) The effect of tyrosinase inhibition for aloe. Planta Medica, 3981, 517-519

12. Lee HJ, Chung MJ, Cho JY, Ham SS, Choe M (2008) Antioxidative and macrophage phagocytic activities and functional component analyses of selected Korean 
chestnut (Castanea crenata S. et Z) cultivars. J Korean Soc Food Sci Nutr, 37, 1095-1100

13. Jang MJ, Cheon SJ, Kim HY, Kwoen DJ, Kim HY, Kim SH, Lee JT (2011) The anti-wrinkle and whitening effect of extracts of Castanea crenata inner shell. J Life Sci, 21, 734-738

14. Singleton VL, Rossi JA (1965) Colorimetry of total phenolics with phosphomolybdic-phosphotungstic acid reagents. Am J Enol Vitic, 16, 144-158

15. Jia Z, Tang M, Wu J (1999) The determination of flavonoid contents in mulberry and their scavenging effects on superoxide radicals. Food Chem, 64, 555-559

16. Duval B, Shetty K (2001) The stimulation of phenolics and antioxidant activity in pea (Pisum sativum) elicited by genetically transformed anise root extract. J Food Biochem, 25, 361-377

17. Dubois M, Gilles KA, Hamilton JK, Rebers PA, Smith F (1956) Colorimetric method for determination of sugars and related substances. J Anal Chem, 28, 350-356

18. Blois MS (1958) Antioxidant determinations by the use of a stable free radical. Nature, 181, 1199-1200

19. Re R, Pellegrini N, Proteggente A, Pannala A, Yang M, Rice-Evans C (1999) Antioxidant activity applying an improved ABTS radical cation decolorization assay. Free Radical Biol Med, 26, 1231-1237

20. Benzie IF, Strain JJ (1996) The ferric reducing ability of plasma (FRAP) as a measure of "antioxidant power": the FRAP assay. Anal Biochem, 239, 70-76

21. Oyaizu M (1986) Studies on products of browning reaction:antioxidative activities of products of browning reaction prepared from glucosamine. Jpn J Nutr Diet, 44, 307-315

22. James AEK, Timothy DW, Gordon L (1996) Inhibition of human leukocyte and porcine pancreatic elastase by homologues of bovine pancreatic tyrosin inhibitor. Biochemistry, 35, 9090-9096

23. Shahidi F, Janitha PK, Wanasundara PD (2009) Phenolic antioxidant. Crit Rev Food Sci Nutr, 32, 67-103

24. Choi MO, Kim BJ, Jo SK, Jung HK, Lee JT, Kim HY, Kweon DJ (2013) Anti-allergic activities of Castanea crenta inner shell extracts fermented by Lactobacillus bifermentans. Korean J Food Preserv, 20, 583-591

25. Jo HE, Chong MS, Choi YH (2010) Evaluation of composition and antioxidant activity form Zizyphus jujuba fruits and leaves extracts for development medicinal food. Korean J orient Physiol Pathol, 24, 859-865
26. Hwang IG, Woo KS, Kim TM, Kim DJ, Yang MH, Jeong HS (2006) Change of physicochemical characteristics of Korean pear (Pyrus pyrifolia Nakai) juice with heat treatment conditions. Korean J Food Sci Technol, 38, 342-347

27. Shouqin Z, Junjie Z, Changzhen W (2004) Novel high pressure extraction technology. Int J Pharm, 278, 471-474

28. Koo SY, Cha KH, Lee DU (2007) Effects of high hydrostatic pressure of foods and biological system. Food Science and Industry, 40, 23-30

29. Tobin D, Thody AJ (1994) The superoside anion may mediate short-but not long-term effects of ultraviolet radiation on melanogenesis. Exp Dermatol, 3, 99-105

30. Bernadette E, Marianne P, Berngard P (1998) Protective effect against sunburn of combined systemic ascorbic acid (vitamin C) and d-a-tocopherol (vitamin E). J Am Acad Dermatol, 38, 45-48

31. Kim EY, Baik IH, Kim JH, Kim SR, Rhyu MR (2004) Screening of the antioxidant activity of some medicinal plants. Korean J Food Sci Technol, 36, 333-338

32. Yoo KH, Jeong JM (2009) Antioxidative and antiallergic effect of persimmon leaf extracts. J Korean Soc Food Sci Nutr, 38, 1691-1698

33. Kwon OC, Woo KS, Kim TM, Kim DJ, Hong JT, Jeong HS (2006) Physicochemical characteristics of garlic (Allium sativum L.) on the high temperature and pressure treatment. Korean J Food Sci Technol, 38, 331-336

34. Sim GS, Kim JH, Lee BC, Lee DH, Lee GS, Pyo HB (2008) Inhibitory effects on melanin production in B16 melanoma cells of Sedum sarmentosum. Yakhak Hoeji, 52, 165-171

35. Kim SJ, Heo MY, Bae KH, Kang SS, Kim HP (2003) Tyrosinase inhibitory activity of plant extract (III): Fifty Korean indigenous plants. J Appl Phamacol, 11, 245-248

36. Kim YJ, Uyama H (2005) Tyrosinase inhibitors from natural and synthetic sources: Structure, inhibition mechanism and perspective for the future. Cell Mol Life Sci, 62, 1707-1723

37. Boissy RE, Manga P (2004) On the etiology of contact/occupational vitiligo. Pigm Cell Res, 17, 208-214

38. Yang MJ, Lim SJ, Ahn HS, Kim MA, Ahn RM (1999) Inhibitory effects of chestnut bark extracts on tyrosinase activity and melanin biosynthesis. Korean J Environ Health Soc, 25, 37-43

39. Yang MJ, Kim MG, Lim SJ, Ahn HS, Ahn RM (1999) Inhibitory effects of water-acetone extract of chestnut inner shell, pine needle and hop on the melanin 
biosynthesis. Yakhak Hoeji, 43, 494-501

40. Dewitt DL, Rollins TE, Day JS, Gauger JA, Smith WL (1981) Orientation of the active site, and antigenic determinants of prostaglandin endoperoxide of synthase in the endoplasmic reticulum. J Biol Chem, 256, 10375-10382

41. Kim MK, Kim JY, Choi SW, Hong JT, Yoon KS (2004) Anti-wrinkle effect of safflower (Cathamus tinctorius L.) seed extract. J Soc Cosmet Sci Korea, 30, 15-22
42. Jeong HR, Kim JH, Jo YN, Jeong JH, Heo HJ (2011) Characterization as cosmetic substances of chestnut inner skim extract with antioxidant activity. J Agric Life Sci, 45, 183-191

43. Kwak YJ, Lee DH, Kim NM, Lee JS (2005) Screening and extraction condition of anti-skin aging elastase inhibitor from medicinal plants. Korean J Medicianl Crop Sci, 13, 213-216 